Recened bo osh

OCT 151991

NUREG/CR-5764 PNL-7594

\title{
Auxiliary Feedwater System Risk-Based Inspection Guide for the Ginna Nuclear Power Plant
}

Prepared by

R. Pugh, B. F. Gore, T. V. Vo, N. E. Moffitt

Pacific Northwest Laboratory

Operated by

Battelle Memorial Institute

Prepared for

U.S. Nuclear Regulatory Cummission 


\section{AVAILABILITY NOTICE}

Avalability of Reference Materials Cited in NRC Publications

Most documents cited in NRC publications will be avallable from one of the following sources:

1. The NRC Public Document Room, 2120 L Street, NW., Lower Level, Washington, DC 20555

2. The Superintendent of Documents, U.S. Government Printing Office, P.O. Box 37082. Washington, DC 20013-7082

3. The National Technical Information Service, Springfield, VA 22161

Although the listing that follows represents the majority of documents cited in NRC publications, it is not intended to be exhaustive.

Referenced documents avallable for inspection and copying for a fee from the NRC Public Document Room include NRC correspondence and internal NRC memoranda; NRC bulletins, circulars, information notices, Inspection and Investigation notices; llcensee event reports; vendor reports and correspondence; Commission papers; and applicant and licensee documents and correspondence.

The following documents in the NUREG series are available for purchase from the GPO Sales Program: formal NRC staff and contractor reports, NRC-sponsored conference proceedings, international agreement reports, grant publications, and NRC booklets and brochures. Also avallable are regulatory guides, NRC regulations in the Code of Federal Regulations, and Nuclear Regulatory Commission Issuances.

Documents available from the National Technical Information Service include NUREG-series reports and technical reports prepared by other Federal agencles and reports prepared by the Atomic Energy Commisslon. forerunner agency to the Nuclear Regulatory Commission.

Documents available from public and special technical libraries include all open literature items, such as books, Journal articles, and transactions. Federal Register notices. Federal and State legislation, and congressional reports can usually be obtained from these libraries.

Documents such as theses, dissertations, foreign reports and translations, and non-NRC conference proceedings are available for purchase from the organization sponsoring the publication cited.

Single copies of NRC draft reports are avallable free, to the extent of supply, upon written request to the Office of Administration, Distribution and Mail Services Section. U.S. Nuclear Regulatory Commission. Washington, DC 20555.

Copies of industry codes and standards used in a substantive manner in the NRC regulatory process are maintained at the NRC Library, 7920 Norfolk Avenue. Bethesda, Maryland, for use by the public. Codes and standards are usually copyrighted and may be purchased from the orlginating organization or, If they are American National Standards, from the American National Standards Institute, 1430 Broadway. New York. NY 10018.

\section{DISCLAIMER NOTICE}

This report was prepared as an account of work sponsored by an agency of the United States Government. Neither the United States Government nor any agency thereof, or any of their employees, makes any warranty, expressed or implied, or assumes any legal liability of responsibility for any third party's use, or the resisits of such use, of any information, apparatus, product or process disclosed in this report, or represents that its use by such third party would not infringe privately owned rights. 


\section{Auxiliary Feedwater System Risk-Based Inspection Guide for the Ginna Nuclear Power Plant}

Manuscript Completed: August 1991

Date Published: September 1991

Prepared by

R. Pugh, B. F. Gore, T. V. Vo, N. E. Moffitt

Pacific Northwest Laboratory

Richland, WA 99352

\section{Prepared for}

Division of Radiation Protection and Emergency Preparedness

Office of Nuclear Reactor Regulation

U.S. Nuclear Regulatory Commission

Washington, DC 20555

NRC FIN L1310

\section{DISCLAIMER}

This report was prepared as an account of work sponsored by an agency of the United States Government. Neither the United States Government nor any agency thereof, nor any of their employees, makes any warranty, express or implied, or assumes any legal liability or responsibility for the accuracy, completeness, or usefulness of any information, apparatus, product, or process disclosed, or represents that its use would not infringe privately owned rights. Reference herein to any specific commercial product, process, or service by trade name, trademark, manufacturer, or otherwise does not necessarily constitute or imply its endorsement, recommendation, or favoring by the United States Government or any agency thereof. The views and opinions of authors expressed herein do not necessarily state or reflect those of the United States Government or any agency thereof. 


\section{SUMMARY}

This document presents a compilation of auxiliary feedwater (AFW) system failure information which has been screened for risk significance in terms of failure frequency and degradation of system performance. It is a riskprioritized listing of failure events and their causes that are significant enough to warrant consideration in inspection planning at Ginna Nuclear Power Plant. This information is presented to provide inspectors increased resources for inspection planning at Ginna.

The risk importance of various component failure modes was identified by analysis of the results of probabilistic risk assessments (PRAs) for many presssurized water reactors (PWRs). Howevser, the component failure categories identified in PRAs are rather broad, because the failure data used in the PRAs is an aggregate of many individual failures having a variety of root causes. In order to help inspectors to focus on specific aspects of componenet operation, maintenance and design which might cause these failures, an extensive review of component failure information was performed to identify the rank and root causes of these component failures. Both Ginna and industry-wide failure information was analyzed. Failure causes were sorted on the basis of frequency of occurrence and seriousness of consequence, and categorized as common cause failures, human errors, design problems, or component failures.

This information is presented in the body of this document. Section 3.0 provides brief descriptions of these risk-important failure causes, and Section 5.0 presents more extensive discussions, with specific examples and references. The entries in the two sections are cross-referenced. An abbreviated system walkdown table is presented in Section 3.2 which includes only components identified as risk important. This table lists the system lineup for normal, standby system operation.

This information permits an inspector to concentrate on components important to the prevention of core damange. However, it is important to note that inspections should not foucs exclusively on these components. Other components which perform essential functions, but which are not included because of high reliability or redundancy, must also be addressed to ensure that degradation does not increase their failure probabilities, and hence their risk importances. 


\section{CONTENTS}

SUMMARY.

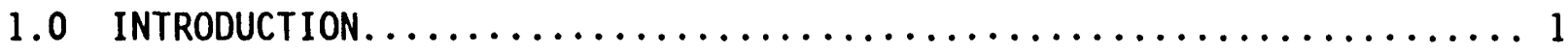

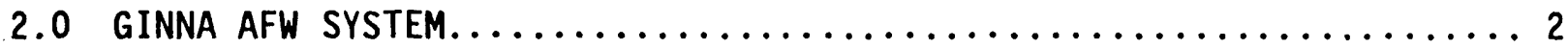

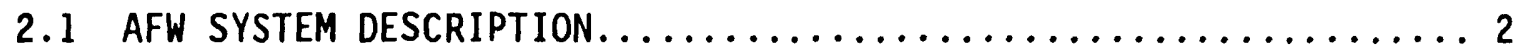

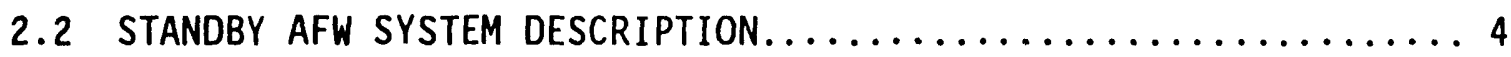

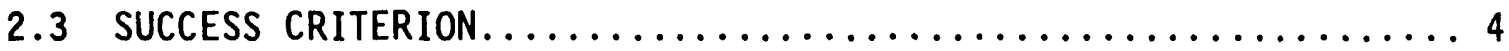

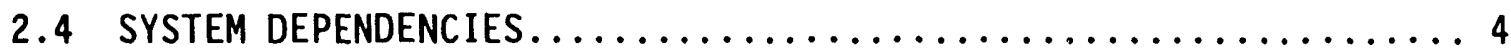

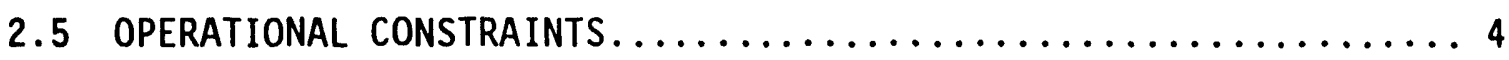

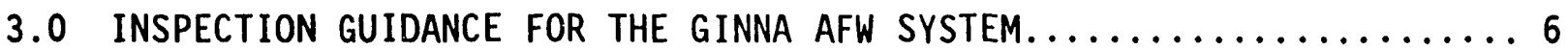

3.1 RISK IMPORTANT AFW COMPONENTS AND FAILURE MODES $\ldots \ldots \ldots \ldots \ldots 6$

3.1.1 Multiple Pump Failures Due to Common Cause............ 6

3.1.2 Turbine Driven Pump PFW04 Fails to Start or Run........7

3.1.3 Motor Driven Pump PFW02A or PFW02B Fails to Start

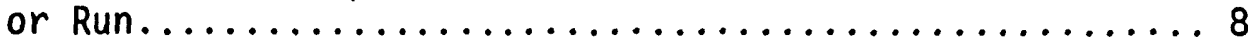

3.1.4 Pump PFW02A, PFW02B, or PFW04 Unavailable Due to Maintenance or Surveillance................ 8

3.1.5 Motor Operated Flow Cortrol Valves - 3996, 4007, or 4008

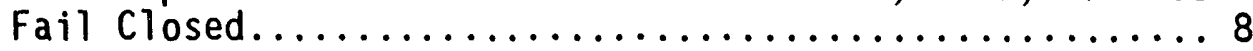

3.1.6 Manual Suction or Discharge Valves Fail Closed......... 9

3.1.7 Air Operated Flow Control Valves Fail Closed.......... 9

3.1.8 Leakage of Hot Feedwater Through Check Valves......... 10

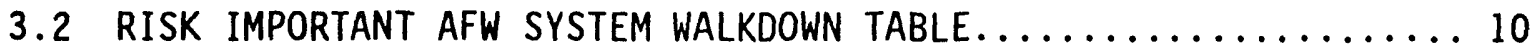

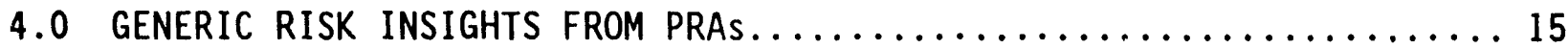

4.1 RISK IMPORTANT ACCIDENT SEQUENCES INVOLVING AFW SYSTEM

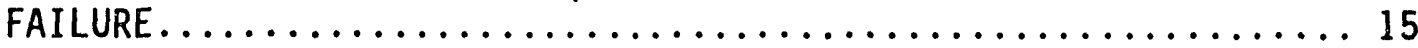

4.2 RISK IMPORTANT COMPONENT FAILURE MODES $\ldots \ldots \ldots \ldots \ldots \ldots \ldots \ldots$ 


\section{CONTENTS}

(Continued)

5.0 FAILURE MODES DETERMINED FROM OPERATING EXPERIENCE.......... 17

5.1 GINNA EXPERIENCE $\ldots \ldots \ldots \ldots \ldots \ldots \ldots \ldots \ldots \ldots \ldots \ldots \ldots \ldots \ldots \ldots$

5.2 INDUSTRY WIDE EXPERIENCE. $\ldots \ldots \ldots \ldots \ldots \ldots \ldots \ldots \ldots \ldots \ldots \ldots$

5.2 .1 Common Cause Failures...................... 18

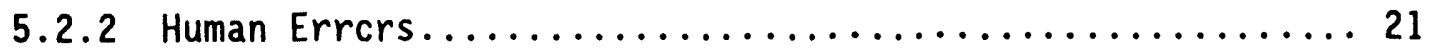

5.2.3 Design/Engineering Problems and Errors............ 21

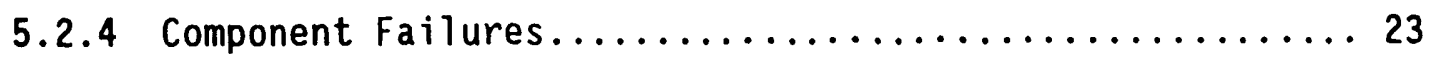

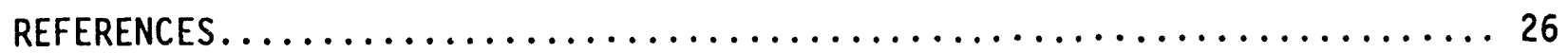




\subsection{INTRODUCTION}

This document is the eighth of a series providing plant-specific inspection guidance for auxiliary feedwater (AFW) systems at pressurized water reactors (PWRs). This guidance is based on information from probabilistic risk assessments (PRAs) for similar PWRs, industry-wide operating experience with AFW systems, plant-specific AFW system descriptions, and plant-specific operating experience. It is not a detailed inspection plan, but rather a compilation of AFW system failure information which has been screened for risk significance in terms of failure frequency and degradation of system performance. The result is a risk-prioritized listing of failure events and their causes that are significant enough to warrant consideration in inspection planning at Ginna.

This inspection guidance is presented in Section 3.0, following a description of the Ginna AFW system in Section 2.0. Section 3.0 identifies the risk important system components by Ginna identification number, followed by brief descriptions of each of the various failure causes of that component. These include specific human errors, design deficiencies, and hardware failures. The discussions also identify where common cause failures have affected multiple, redundant components. These brief discussions identify specific aspects of system or component design, operation, maintenance, or testing for inspection by observation, records review, training observation, procedures review, or by observation of the implementation of procedures. An AFW system walkdown table identifying risk important components and their lineup for normal, standby system operation is also provided.

The remainder of the document describes and discusses the information used in compiling this inspection guidance. Section 4.0 describes the risk importance information which has been derived from PRAs and its sources. As review of that section will show, the failure categories identified in PRAs are rather broad (e.g., pump fails to start or run, valve fails closed). Section 5.0 addresses the specific failure causes which have been combined under these categories.

AFW system operating history was studied to identify the various specific failures which have been aggregated into the PRA failure mode categories. Section 5.1 presents a summary of Ginna failure information, and Section 5.2 presents a review of industry-wide failure information. The industry-wide information was compiled from a variety of NRC sources, including AEOD analyses and reports, information notices, inspection and enforcement bulletins, and generic letters, and from a variety of INPO reports as we11. Some Licensee Event Reports and NPRDS event descriptions were also reviewed individually. Finally, information was included from reports of NRCsponsored studies of the effects of plant aging, which include quantitative analyses of reported AFW system failures. This industry-wide information was then combined with the plant-specific failure information to identify the various root causes of the PRA failure categories, which are identified in Section 3.0 . 


\subsection{GINNA AFW SYSTEM}

This section presents an overview description of the Ginna AFW system, including a simplified schematic system diagram. In addition, the system success criterion, system dependencies, and administrative operational constraints are also presented.

\subsection{AFW SYSTEM DESCRIPTION}

The AFW system provides feedwater to the steam generators (SG) to allow secondary-side heat removal from the primary system when main feedwater is unavailable. The system is capable of functioning for extended periods, which allows time to restore main feedwater flow or to proceed with an orderly cooldown of the plant to where the residual heat removal (RHR) system can remove decay heat. A simplified schematic diagram of the AFW system is shown in Figure 2.1.

The system is capable of supplying water at a pressure equal to or greater than the lowest main steam safety valve setpoint ( $p$ lus error accumulation - 1085 psig) within one minute after an automatic start signal is received. All three pumps start on receipt of a steam generator low-low level signal. (The motor driven pumps start on low-low level in one SG, whereas, low-low level signals from both $S / G$ s are required for a turbine driven pump start.) Both motor driven (MD) pumps start on a trip of both MFW pumps, a safety injection signal or an ATWS Mitigation System Actuation Circuit (AMSAC) actuation. The single turbine driven (TD) pump starts on undervoltage on both $4160 \mathrm{~V}$ buses or an AMSAC actuation.

The normal AFW pump suction is from two cross connected 30,000 gallon capacity condensate storage tanks (CSTs). Each pump draws from a common header through a locked-open isolation valve and a check valve. Power, control, and instrumentation associated with each motor-driven pump are independent from one another. Steam for the turbine driven pump is supplied by either or both steam generators $1 \mathrm{~A}$ or $1 \mathrm{~B}$ from a point upstream of the main steam isolation valves, through valve 3652. Each AFW pump is equipped with a recirculation flow system, which prevents pump deadheading.

Each auxiliary feedwater pump discharge is provided with a check valve. This is followed by two flow control valves in parallel (an open MOV and a closed pneumatic valve), a second check valve, and a manual isolation valve. Each motor-driven pump normally supplies feedwater to only one steam generator, but the headers may be cross-connected. The turbine-driven pump normally supplies both steam generators through an open MOV, a check valve, and in each train, a manual valve, a pneumatic flow control valve, a second manual valve, a check valve and a manual isolation valve.

The CSTs are the normal source of water for the AFW System and are required to store sufficient demineralized water to remove decay heat from the reactor for 2 hours after a reactor scram from full power. AFW suction may also be switched manually to the Station Service Water (SWS) system using alternative suction valves. Because the CST is not seismically qualified, the 


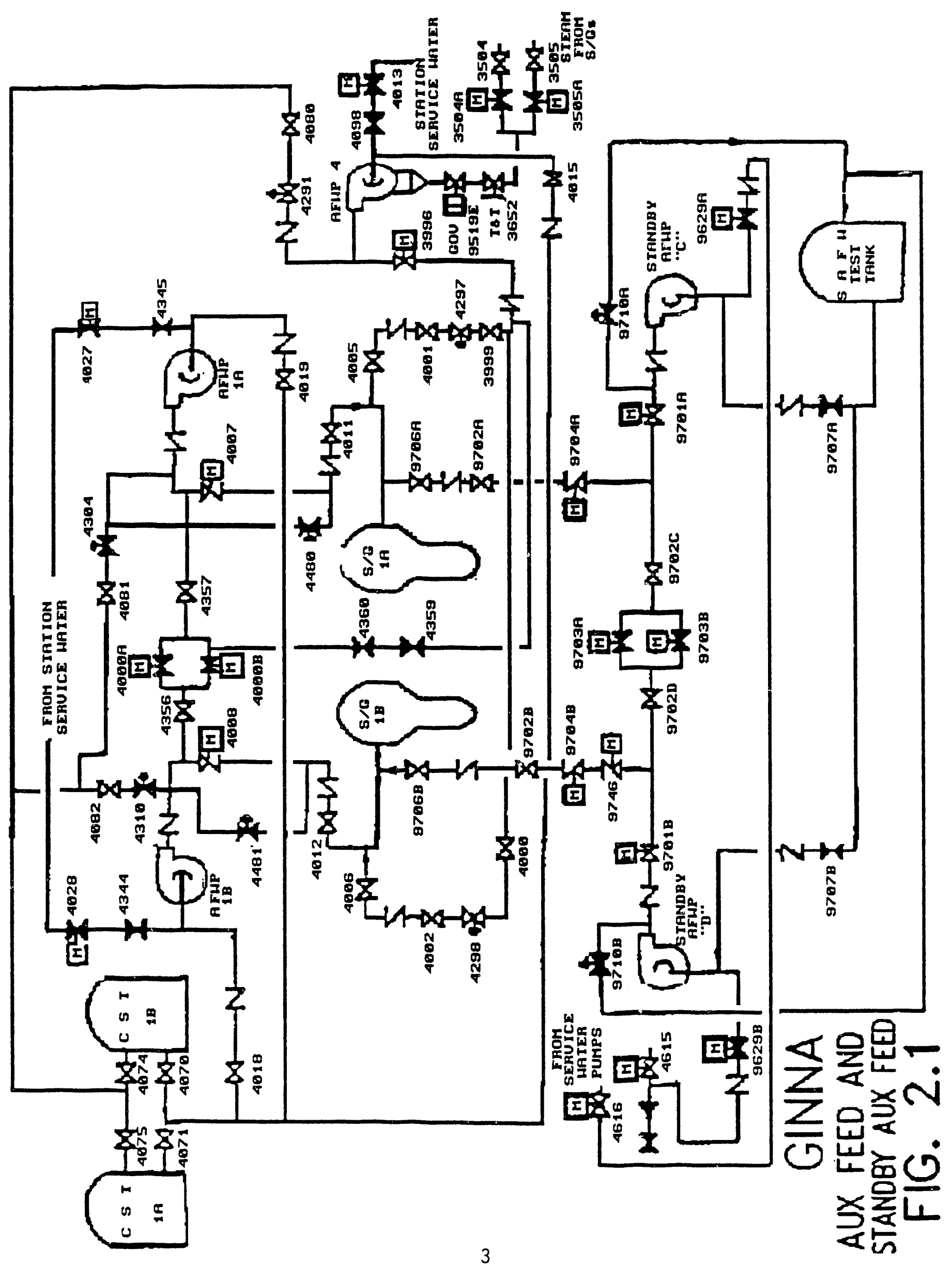


seismic Class I SWS is the suction source used by the safety anaylsis to satisfy the General Design Criterion 2.

\subsection{STANDBY AFW SYSTEM DESCRIPTION}

Because all three trains of the AFW system are vulnerable to a high energy pipe break, a Standby AFW system has been provided, also. It provides a reliable means of residual heat removal in the event that all other sources of feedwater are lost. A simplified schematic diagram of the Standby AFW system is also shown in Figure 2.1.

The system consists of two motor-driven pumps with either pump capable of supplying sufficient feedwater to cool the Reactor Coolant System to the temperature at which the Residual Heat Removal (RHR) System can be utilized for heat removal. Each pump takes suction from its respective service water loop and feeds one steam generator. Cross-connecting the system is possible; however, the trains are usually operated independently and supplied by separate ESF buses. A backup suction supply is available from the fire (city) water system. Previously, this supply required manual connection with fire hoses. Fermanent piped connections are currently (June 1991) being installed.

The standby system does not start automatically, but is started and operated manually from the main control room. In the event that an AFW pipe breaks outside containment, or all means of feedwater supply are lost, the operator would be alerted by existing control room indication. The operator would manually remove the affected AFW pump from the bus and place the standby pump into operation on the same bus. Flow is controlled by throttling the discharge valve. For operational tests, manually operated valves in the supply line from the standby auxiliary condensate test tank must be opened and adequate tank level verified before starting either pump.

\subsection{SUCCESS CRITERION}

System success requires the operation of at least one pump supplying rated flow to at least one of the two steam generators.

\subsection{SYSTEM DEPENDENCIES}

The AFW system depends on AC power for motor-driven pumps and level control valves, DC power for control power to pumps and valves, and an automatic actuation signal. An adequate air supply is required for the operation of certain bypass and flow control valves. The turbine-driven pump also requires steam availability.

\subsection{OPERATIONAL CONSTRAINTS}

When the reactor is critical the Ginna Technical Specifications Action Statements require the plant to be shutdown for any of the following inoperability/duration conditions:

- Inoperability of one MDAFW pump or one flowpath from the TDAFW pump to a steam generator exceeding 7 days, 
- Inoperability of the TDAFW pump or the flow paths from the TDAFW pump to both steam generators exceeding 72 hours,

- Inoperability of two AFW pumps exceeding 72 hours,

- Inoperability of one standby AFW pump or flowpath exceeding 14 days,

- Inoperability of both standby AFW pumps exceeding 72 hours.

In each case when shutdown is required, the plant must be in Hot Shutdown within 6 hours and average RCS temperature reduced to below 350 degrees within the following 6 hours.

The Ginna Technical Specifications require a minimum combined volume of 22,500 gallons of water to be stored in the CSTs. If CST inventory is less than 22,500 for more than four hours, the operability of the service water system as a backup AFW supply must be demonstrated or the plant must be in hot shutdown within the following 6 hours. 


\subsection{INSPECTION GUIDANCE FOR THE GINNA AFW SYSTEM}

In this section the risk important components of the Ginna AFW system are identified, and the important modes by which they are likely to fail are briefly described. These failure modes include specific human errors, design problems, and types of hardware failures which have been observed to occur for these types of components, both at Ginna and at PWRs throughout the nuclear industry. The discussions also identify where common cause failures have affected multiple, redundant components. These brief discussions identify specific aspects of system or component design, operation, maintenance, or testing for observation, records review, training observation, procedures review or by observation of the implementation of procedures.

Table 3.1 is an abbreviated AFW system walkdown table which identifies risk important components. This table lists the system lineup for normal, standby system operation. Inspection of the components identified addresses essentially all of the risk associated with AFW system operation.

\subsection{RISK IMPORTANT AFW COMPONENTS AND FAILURE MODES}

Common cause failures of multiple pumps are the most risk-important failure modes of AFW system components. These are followed in importance by single pump failures, level control valve failures, and individual check valve backleakage failures.

The following sections address each of these failure modes, in decreasing order of importance. They present the important root causes of these component failure modes which have been distilled from historical records. Each item is keyed to discussions in Section 5.2 which present additional information on historical events.

\subsubsection{Multiple Pump Failures Due to Common Cause}

The following listing summarizes the most important multiple-pump failure modes identified in Section 5.2.1, Common Cause Failures, and each item is keyed to entries in that section..

- Incorrect operator intervention into automatic system functioning, including improper manual starting and securing of pumps, has caused failure of all pumps, including overspeed trip on startup, and inability to restart prematurely secured pumps. CC1.

- Valve mispositioning has caused failure of all pumps. Pump suction, stearn supply, and instrument isolation valves have been involved. CC2.

Steam binding has calised failure of multiple pumps. This resulted from leakage of hot feedwater past check valves into a common discharge header, with several valves involved including a motor-operated discharge valve. (See item 7 below.) CC10. Multiple-pump steam 
binding has also resulted from improper valve lineups, and from running a pump deadheaded. CC3.

- Pump control circuit deficiencies or design modification errors have caused failures of multiple pumps to auto stari, spurious pump trips during operation, and failures to restart after pump shutdown. CC4. Incorrect setpoints and control circuit calibrations have also prevented proper operation of multiple pumps. CC5.

- Loss of a vital power bus has failed both the Lurbine-driven and one motor-driven pump due to luss of control prwer to steam admission valves or to turbine contiols, and to motor controls powered from the same bus. CC6.

- Simultaneous startup of multiple pumps has caused oscillations of pump suction pressure causing multiple-pump trips on low suction pressure, despite the existence of adequate static net positive suction head (NPSH). CC7. Design reviews have identified inadequately sized suction piping which could have yielded insufficient NPSH to support operation of more than one pump. CC8.

\subsubsection{Turbine Driven Pump PFW04 Fails to Start or Run}

- Improperly adjusted and inadequately maintained turbine governors have caused pump failures. HE2. Problems include worn or loosened nuts, set screws, linkages or cable connections, oil leaks and/or contamination, and electrical failures of resistors, transistors, diodes and circuit cards, and erroneous grounds and connections. CF5.

- Terry turbines with Woodward Model EG governors have been found to overspeed trip if full steam flow is allowed on startup. Sensitivity can be reduced if a startup steam bypass valve is sequenced to open first. DEl.

- Condensate slugs in steam lines have caused turbine overspeed trip on startup. Tests repeated right after such a trip may fail to indicate the problem due to warming and clearing of the steam lines.

Surveillance should exercise all steam supply connections. DE2.

- Trip and throttle valve (3652) problems which have failed the turbine driven pump include physically bumping it, failure to reset it following testing, and failures to verify control room indication of reset. HE2. Whether either the overspeed trip or TTV trip can be reset without resetting the other, indication in the control room of TTV position, and unambiguous local indication of an overspeed trip affect the likelihood of these errors. DE3.

- Turbines with Woodward Model PG-PL governors have tripped on overspeed when restarted shortly after shutdown, unless an operator has locally exercised the speed setting knob to drain oil from the governor speed setting cylinder (per procedure). Automatic oil dump valves are now available through Terry. DE4. 


\subsubsection{Motor Driven Pump PFWO2A or PFWO2B Fails to Start or Run}

- Control circuits used for automatic and manual pump starting are an important cause of motor driven pump failures, as are circuit breaker failures. CF7.

- Mispositioning of handswitches and procedural deficiencies have prevented automatic pump start. HE3.

- Low lubrication oil pressure resulting from heatup due to previous operation has prevented pump restart due to failure to satisfy the protective interlock. DE5.

\subsubsection{Pump PFWO2A, PFWO2B or PFW04 Unavailable Due to Maintenance or Surveillance}

- Both scheduled and unscheduled maintenance remove pumps from operability. Surveillance requires operation with an altered line-up, a) though a pump train may not be declared inoperable during testing. Prompt scheduling and performance of maintenance and surveillance minimize this unavailability.

\subsubsection{Motor Operated Flow Control Valves 3996, 4007 or 4008 Fail Closed}

These normally open MOVs control flow from the AFW pumps to each of the steam generators. They faii as-is on loss of power.

- Common cause failure of MOVs has resulted from failure to use electrical signature tracing equipment to determine proper settings of torque switch and torque switch bypass switches. Failure to calibrate switch settings for high torques necessary under design basis accident conditions has also been involved. CC1l.

- Valve motors have been failed due to lack of, or improper sizing or use of thermal overload protective devices. Bypassing and oversizing should be based on proper engineering for design basis conditions. CF4.

- Out-of-adjustment electrical flow controllers have caused improper discharge valve operation, affecting multiple trains of AFW. CCl2.

- Grease trapped in the torque switch spring pack of Limitorque SMB motor operators has caused motor burnout or thermal overload trip by preventing torque switch actuation. CF8.

- Manually reversing the direction of motion of operating MOVs has overloaded the motor circuit. Operating procedures should provide cautions, and circuit designs may prevent reversal before each stroke is finished. DE7. 
Space heaters designed for preoperation storage have been found wired in parallel with valve motors which had not been environmentally qualified with them present. DE8.

\subsubsection{Manual Suction or Discharge Valves Fail Closed}

AFW Pump PFWO2A, PFW02B, PFW04 Suction Valves: $4019,4018,4015$
MD Pump PFW02A Discharge Valve: 4011
MD Pump PFW02B Discharge Valve: 4012
TD Pump PFW04 Discharge to IA S/G: $3999,4001,4005$
TD Pump PFW04 Discharge to IB S/G:4000,4002, 4006

These manual valves are normally locked open. Closure of the suction valves listed would block suction from the CSTs to their respective AFW pump. Closure of the discharge valves listed would block pump discharge to their respective $S / G$ but would not block the recirculation flowpath to the CST.

- Valve mispositioning has resulted in failures of multiple trains of AFW. CC2. It has also been the dominant cause of problems identified during operational readiness inspections. HEl. Events have occurred most often during maintenance, calibration, or system modifications. Important causes of mispositioning include:

Failure to provide complete, clear, and specific procedures for tasks and system restoration

Failure to promptly revise and validate procedures, training, and diagrams following system modifications

Failure to complete all steps in a procedure

Failure to adequately review uncompleted procedural steps after task completion

Failure to verify support functions after restoration

- Failure to adhere scrupulously to administrative procedures regarding tagging, control and tracking of valve operations Failure to log the manipulation of sealed valves

Failure to follow good practices of written task assignment and feedback of task completion information

Failure to provide easily read system drawings, legible valve labels corresponding to drawings and procedures, and labeled indications of local valve position

\subsubsection{Air Operated Flow Control Valves Fail Closed}

TD Pump Trains: 4297,4298
MD Pump Trains: 4480,4481

These normally-open air operated valves (AOVs) in the turbine-driven pump trains control flow to the steam generators. In the motor-driven pump trains these bypass valves are normally closed. They all fail open on loss of Instrument Air.

- Control Circuit problems have been a primary cause of failures, both at Ginna and elsewhere. CF9. Valve failures have resulted 
from blown fuses, failure of control components (such as current/pneumatic convertors), broken or dirty contacts, misaligned or broken limit switches, control power loss, and calibration problems. Degraded operation has also resulted from improper air pressure due to air regulator failure or leaking air lines.

- Out-of-adjustment electrical flow controllers have caused improper valve operation, affecting multiple trains of AFW. CC12.

- Leakage of hot feedwater through check valves has caused thermal binding of flow control MOVs. AOVs may be similarly susceptible. CF2.

- Multiple flow control valves have been plugged by clams when suction switched automatically to an alternate, untreated source. CC9.

\subsubsection{Leakage of Hot Feedwater through Check Valves:}

Between Pump PFW04 and MFW: Valves 4004, 4003
Between Pump PFWO2A and MFW: Valves 4000C
Between Pump PFW02B and MFW: Valves 4000D
At Pump Discharges: Valves $3998,4010,4009$

- Leakage of hot feedwater through several check valves in series has caused steam binding of multiple pumps. Leakage through a closed level control valve in series with check valves has also occurred. CC10.

- Slow leakage past the final check valve of a series may not force upstream check valves closed, allowing leakage past each of them in turn. Piping orientation and valve design are important factors in achieving true series protection. CFl.

\subsection{RISK IMPORTANT AFW SYSTEM WALKDOWN TABLE}

Table 3.1 presents an AFW system walkdown table including only components identified as risk important. This information allows inspectors to concentrate their efforts on components important to prevention of core damage. However, it is essential to note that inspections should not focus exclusively on these components. Other components which perform essential functions, but which are absent from this table because of high reliability or redundancy, must also be addressed to ensure that their risk importances are not increased. Examples include an adequate water level in the CST, and the (closed) valves cross connecting the discharges of the two motor-driven AFW pumps . 
IABLE 3.1. Risk Important AFW System Walkdown Table

\begin{tabular}{|c|c|c|c|c|}
\hline Component \# & Component Name & Location & $\begin{array}{l}\text { Required } \\
\text { Position }\end{array}$ & $\begin{array}{c}\text { Actual } \\
\text { Position }\end{array}$ \\
\hline
\end{tabular}

\section{Electrical}

\begin{tabular}{|c|c|c|}
\hline PFW02A & Motor-Driven Pump Breaker & $\begin{array}{l}\text { Racked In/ } \\
\text { Closed }\end{array}$ \\
\hline PFW02B & Motor-Driven Pump Breaker & $\begin{array}{l}\text { Racked In/ } \\
\text { Closed }\end{array}$ \\
\hline \multicolumn{3}{|c|}{ PFW02A Flowpath } \\
\hline 4019 & CST to MDP PFWO2A Suction Valve & Locked Open \\
\hline 4027 & MDP PFW02A Service Water Supply & Closed \\
\hline 4345 & MOP PFW02A Service Water Isolation & Locked Closed \\
\hline 4007 & AFW MDP PFWO2A Discharge Valve & Open \\
\hline 4480 & MDP PFW02A Flow Control Bypass & Closed \\
\hline $4 \cap 11$ & MDP S/G IA Isolation & Locked Open \\
\hline \multicolumn{3}{|c|}{ PFW02B Flowpath } \\
\hline 4018 & CST to MDP PFWO2B Suction Val\%e & Locked Open \\
\hline 4028 & MDP PFW02B Service Water Supply & Closed \\
\hline 4344 & MDP PFW02B Service Water Isolation & Locked Closed \\
\hline 4008 & AFW S.DP PFWO2B Discharge Valve & Open \\
\hline 4481 & MDP PFW02B Flow Control Bypass & Closed \\
\hline 4012 & MDP S/G IB Isolation & Locked Open \\
\hline \multicolumn{3}{|c|}{ PFW04 Flowpath } \\
\hline 4015 & CST to TDP PFW04 Suction Valve & Locked Open \\
\hline 4013 & TDP PFW4 Service Water Supply & Closed \\
\hline 4098 & TDP PFW4 Service Water Isolation & Locked Closed \\
\hline
\end{tabular}


TABLE 3.1. Risk Important AFW System Walkdown Table (Continued)

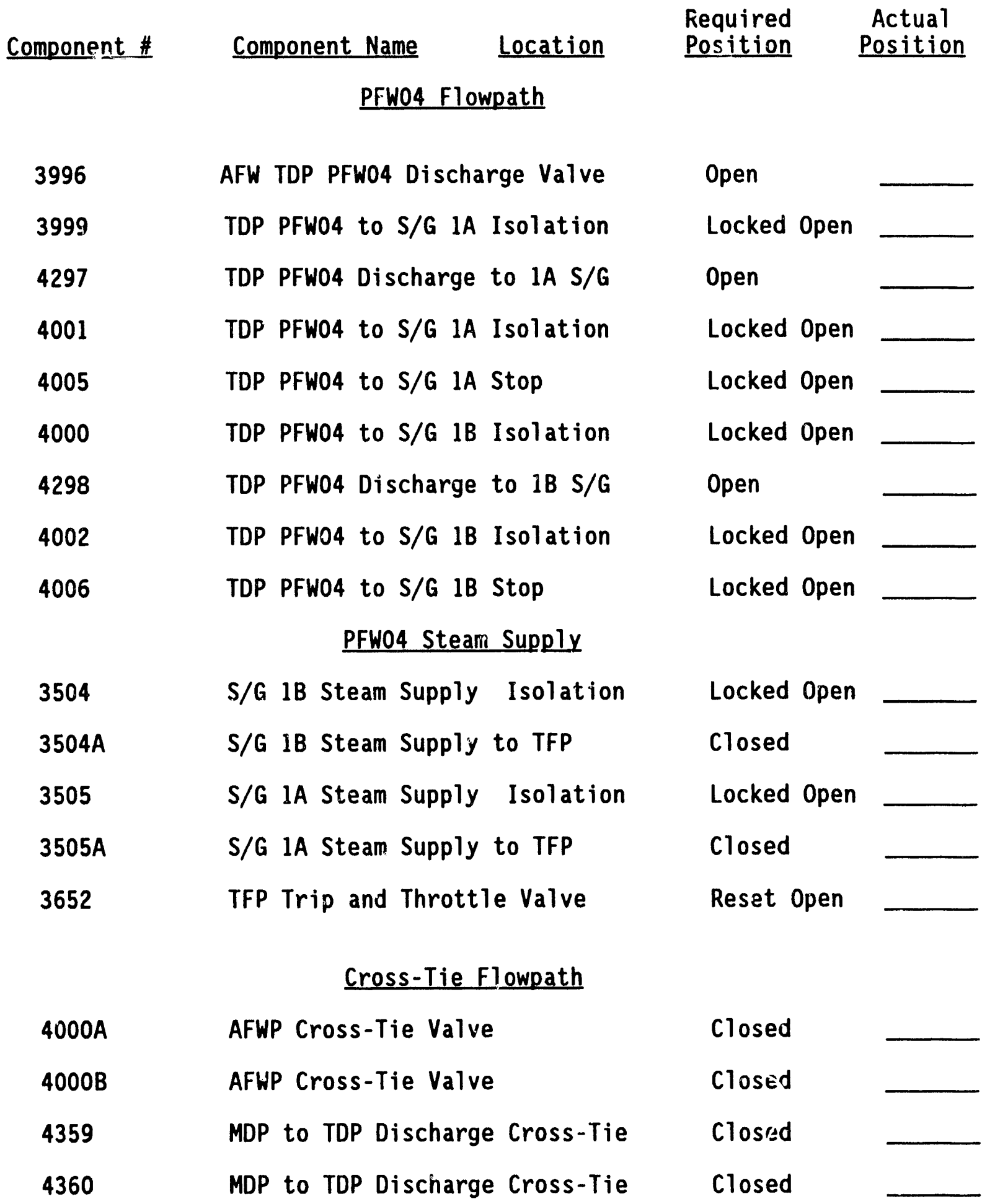


IABLE 3.1. Risk Important AFW System Walkdown Table (Cont inued)

\section{CST I solation}

4070

1B CST Isolation Valve

Locked Open

4071

IA CST Isolation Valve

Locked Open

Standby AFW System

D SAFWP

Breaker

Racked In

Breaker

Racked In

"C" SAFWP Flowpath

4616

Service Water MOV Isolation

Open

$9629 A$

C SAFWP Service Water Supply

Closed

9701A

C SAFWP Discharge Valve

Open

9704A

C SAFWP Discharge CNMT Isolation Open

9702A

C SAFWP Manual CNMT Isolation

Locked Open

9706A

C SAFWP to $S / G$ IA Locked Open

$9710 \mathrm{~A}$

C SAFWP Recirc Valve

Closed

\section{"D" SAFWP Flowpath}

4615

Service Water MOV Isolation

Open

9629B

D SAFWP Service Water Supply

Closed

9701B

D SAFWP Discharge Valve

Open

9746

D SAFWP Emergency Discharge

Open

9704B

D SAFWP Discharge CNMT Isolation Open

9702B

D SAFWP Manual CNMT Isolation

Locked Open

9706B

D SAFWP to $S / G 1 B$

Locked Open

$9710 \mathrm{~B}$

D SAFWP Recirc Valve

closed 
IABLE 3.1. Risk Important AFW System Walkdown Table (Continued)

$\begin{array}{lcll}\text { Component \# } & \text { Component Name } \quad \underline{\text { Location }} & \begin{array}{c}\text { Required } \\ \text { Position }\end{array} & \begin{array}{c}\text { Actual } \\ \text { Position }\end{array} \\ \text { Cross-Tie Valves } & & \\ 9702 C & \text { SAFWP's Cross-Tie Isolation } & \text { Open } & \\ 9702 D & \text { SAFWP's Cross-Tie Isolation } & \text { Open } & \\ 9703 \mathrm{~A} & \text { SAFWP's MOV Cross-Tie Isolation } & \text { Closed } & \\ 9703 \mathrm{~B} & \text { SAFWP's MOV Cross-Tie Isolation } & \text { Closed } & \end{array}$




\subsection{GENERIC RISK INSIGHTS FROM PRAS}

PRAs for 13 PWRs were analyzed to identify risk-important accident sequences involving loss of AFW, and to identify and risk-prioritize the component failure modes involved. The results of this analysis are described in this section. They are consistent with results reported by INEL and BNL (Gregg et al 1988, and Travis et al, 1988).

\subsection{RISK IMPORTANT ACCIDENT SEQUENCES INVOLVING AFW SYSTEM FAILURE}

\section{Loss of Power System}

- A loss of offsite power is followed by failure of AFW. Due to lack of actuating power, the PORVs cannot be opened, preventing adequate feed-and-bleed cooling, and resulting in core damage.

- Astation blackout fails all AC power except Vital AC from DC invertors, and all decay heat removal systems except the turbine-driven AFW pump. AFW subsequently fails due to battery depletion or hardware failures, resulting in core damage.

- $\quad$ D DC bus fails, causing a trip and failure of the power conversion system. One AFW motor-driven pump is failed by the bus loss, and the turbine-driven pump fails due to loss of turbine or valve control power. AFW is subsequently lost completely due to other failures. Feed-and-bleed cooling fails because PORV control is lost, resulting in core damage.

\section{Transient-Caused Reactor or Turbine Trip}

- A transient-caused trip is followed by a loss of PCS and AFW. Feed-and-bleed cooling fails either due to failure of the operator to initiate it, or due to hardware failures, resulting in core damage.

Loss of Main Feedwater

- A feedwater line break drains the common water source for MFW and AFW. The operators fail to provide feedwater from other sources, and fail to initiate feed-and-bleed cooling, resulting in core damage.

- A loss of main feedwater trips the plant, and AFW fails due to operator error and hardware failures. The operators fail to initiate feed-and-bleed cooling, resulting in core damage. 
Steam Generator Tube Rupture

- A SGTR is followed by failure of AFW. Coolant is lost from the primary until the RWST is depleted. HPI fails since recirculation cannot be established from the empty sump, and core damage results.

\subsection{RISK IMPORTANT COMPONENT FAILURE MODES}

The generic component failure modes identified from PRA analyses as important to AFW system failure are listed below in decreasing order of risk importance.

1. Turbine-Driven Pump Failure to Start or Run.

2. Motor-Driven Pump Failure to Start or Run.

3. TDP or MDP Unavailable due to Test or Maintenance.

4. AFW System Valve Failures

- steam admission valves

- trip and throttle valve

- flow control valves

- pump discharge valves

- pump suction valves

- valves in testing or maintenance.

5. Supply/Suction Sources

- condensate storage tank stop valve

- hot well inventory

- suction valves.

In addition to individual hardware, circuit, or instrument failures, each of these failure modes may result from common causes and human errors. Common cause failures of AFW pumps are particularly risk important. Valve failures are somewhat less important due to the multiplicity of steam generators and connection paths. Human errors of greatest risk importance involve: failures to initiate or control system operation when required; failure to restore proper system lineup after maintenance or testing; and failure to switch to alternate sources when required. 


\subsection{FAILURE MODES DETERMINED FROM OPERATING EXPERIENCE}

This section describes the primary root causes of component failures of the AFW system, as determined from a review of operating histories at Ginna and at other PWRs throughout the nuclear industry. Section 5.1 describes experience at Ginna. Section 5.2 summarizes information compiled from a variety of NRC sources, including AEOD analyses and reports, information notices, inspection and enforcement bulletins, and generic letters, and from a variety of INPO reports as well. Some Licensee Event Reports (LERS) and NPRDS event descriptions were also reviewed individually. Finally, information was included from reports of NRC-sponsored studies of the effects of plant aging, which include quantitative analyses of AFW system failure reports. This information was used to identify the various root causes expected for the broad PRA-based failure categories identified in Section 4.0, resulting in the inspection guidelines presented in Section 3.0.

\subsection{GINNA EXPERIENCE}

Twenty-five events affecting the operational performance and readiness of the AFW system at Ginna were found in AFW operating history data dating back to 1984. Ginna operating history data indicaties failures of the AFW pumps, the pump discharge flow control valves to steam generators, pump suction and discharge valves and system check valves. Failure modes include electrical, instrumentation, hardware failures, and human errors.

\section{AFW Pump Control Logic, Instrumentation and Electrical Failures}

There have been two failures of the AFW or Standby AFW pumps to start or trip experienced since 1984. These have resulted from failure of control power fuses and control bistable operation. The failure causes are improper or inadequate lubrication to a mechanical interlock and improper wiring after system testing.

\section{Failure of AFW Pump Discharge Flow Control Valve to Steam Generator}

There have been two failures of the pump discharge flow control valves since 1984. These have resulted from valve control circuit failures caused by circuit breaker operation and improper control bistable operation. The circuit breaker was found to be missing a fuse clip. Misadjustment of the control bistable prevented full valve travel.

\section{AFW MOV and AOV Valve Failures}

Since 1984 there have been twe've events involving AFW valve failures. Failures have been caused by control relays, torque switch failure or misadjustment, misadjusted spring packs, misaligned engagement levers and binding resultant from foreign material. Failure causes are improper or inadequate testing and maintenance procedures, mechanical wear, and system design flaws. 


\section{Human Errors}

There have been eight significant human errors affecting the AFW system since 1984. Personnel have failed to calibrate equipment or realign equipment in the correct position following maintenance and testing, improperly wired bistables after testing, damaged components during operation or inspection and failed to assemble components correctly or completly after maintenance. Both personnel error and inadequate procedures have been involved. Misunderstanding of operability requirements has resulted in equipment exceeding Technical Specifications operability limits.

\subsection{INDUSTRY WIDE EXPERIENCE}

Human errors, design/engineering problems and errors, and component failures are the primary root causes of AFW System failures identified in a review of industry wide system operating history. Common cause failures, which disable more than one train of this operationally redundant system, are highly risk significant, and can result from all of these causes.

This section identifies important common cause failure modes, and then provides a broader discussion of the single failure effects of human errors, design/engineering problems and errors, and component failures. Paragraphs presenting details of these failure modes are coded (e.g., CC1) and crossreferenced by inspection items in Section 3 .

\subsubsection{Common Cause Failures}

The dominant cause of AFW system multiple-train failures has been human error. Design/engineering errors and component failures have been less frequent, but nevertheless significant, causes of multiple train failures.

CC1. Human error in the form of incorrect operator intervention into automatic AFW system functioning during transients resulted in the temporary loss of all safety-grade AFW pumps during events at Davis Besse (NUREG-1154, 1985) and Trojan (AEOD/T416, 1983). In the Davis Besse event, improper manual initiation of the steam and feedwater rupture control system (SFRCS) led to overspeed tripping of both turbine-driven AFW pumps, probably due to the introduction of condensate into the AFW turbines from the long, unheated steam supply lines. (The system had never been tested with the abnormal, crossconnected steam supply lineup which resulted.) In the Trojan event the operator incorrectly stopped both AFW pumps due to misinterpretation of MFW pump speed indication. The diesel driven pump would not restart due to a protective feature requiring complete shutdown, and the turbine-driven pump tripped on overspeed, requiring local reset of the trip and throttle valve. In cases where manual intervention is required during the early stages of a transient, training should emphasize that actions should be performed methodically and deliberately to guard against such errors.

CC2. Valve misposi ining has accounted for a significant fraction of the human errors failing multiple trains of AFW. This includes closure of normally open suction valves or steam supply valves, and of isolation valves to sensors having control functions. Incorrect handswitch positioning and 
inadequate temporary wiring changes have also prevented automatic starts of multiple pumps. Factors identified in studies of mispositioning errors include failure to add newly installed valves to valve checklists, weak administrative control of tagging, restoration, independent verification, and locked valve logging, and inadequate adherence to procedures. Illegible or confusing local valve labeling, and insufficient training in the determination of valve position may cause or mask mispositioning, and surveillance which does not exercise complete system functioning may not reveal mispositionings.

CC3. At ANO-2, both AFW pumps lost suction due to steam binding when they were 1 ined up to both the CST and the hot startup/blowdown demineralizer effluent (AEOD/C404, 1987). At Zion-1 steam created by running the turbinedriven pump deadheaded for one minute caused trip of a motor-driven pump sharing the same inlet header, as well as damage to the turbine-driven pump (Region 3 Morning Report, 1/17/90). Both events were caused by procedural inadequacies.

CC4. Design/engineering errors have accounted for a smaller, but significant fraction of common cause failures. Problems with control circuit design modifications at Farley defeated AFW pump auto-start on loss of main feedwater. At Zion-2, restart of both motor driven pumps was blocked by circuit failure to deenergize when the pumps had been tripped with an automatic start signal present (IN 82-01, 1982). In addition, AFW control circuit design reviews at Salem and Indian Point have identified designs where failures of a single component could have failed all or multiple pumps (IN 87 $34,1987)$.

CC5. Incorrect setpoints and control circuit settings resulting from analysis errors and failures to update procedures have also prevented pump start and calised pumps to trip spuriously. Errors of this type may remain undetected despite surveillance testing, unless surveillance tests model all types of system initiation and operating conditions. A greater fraction of

instrumentation and control circuit problems has been identified during actual system operation (as opposed to surveillance testing) than for other types of failures.

cc6. On two occasions at a foreign plant, failure of a balance-of-plant inverter caused failure of two AFW pumps. In addition to loss of the motor driven pump whose auxiliary start relay was powered by the invertor, the turbine driven pump tripped on overspeed because the governor valve opened, allowing full steam flow to the turbine. This illustrates the importance of assessing the effects of failures of balance of plant equipment which supports the operation of critical components. The instrument air system is another example of such a system.

CC7. Multiple AFW pump trips have occurred at Millstone-3, Cook-1, Trojan and Zion-2 (IN 87-53, 1987) caused by brief, low pressure oscillations of suction pressure during pump startup. These oscillations occurred despite the availability of adequate static NPSH. Corrective actions taken includie: extending the time delay associated with the low pressure trip, removing the trip, and replacing the trip with an alarm and operator action. 
CC.8. Design errors discovered during AFW system reanalysis at the Robinson plant (IN 89-30, 1989) and at Millstone-1 resulted in the supply header from the CST being too small to provide adequate NPSH to the pumps if more than one of the three pumps were operating at rated flow conditions. This could lead to multiple pump failure due to cavitation. Subsequent reviews at Robinson identified a loss of feedwater transient in which inadequate NPSH and flows less than design values had occurred, but which were not recognized at the time. Event analysis and equipment trending, as well as surveillance testing which duplicates service conditions as much as is practical, can help identify such design errors.

CC9. Asiatic clams caused failure of two AFW flow control valves at Catawba2 when low suction pressure caused by starting of a motor-driven pump caused suction source realignment to the Nuclear Service Water system. Pipes had not been routinely treated to inhibit clam growth, nor regularly monitored to detect their presence, and no strainers were installed. The need for surveillance which exercises alternative system operational modes, ds well as complete system functioning, is emphasized by this event. Spurious suction switchover has also occurred at Callaway and at McGuire, although no failures resulted.

CC10. Common cause failures have also been caused by component failures (AEOD/C404, 1984). At Surry-2, both the turbine driven pump and one motor driven pump were declared inoperable due to steam binding caused by backleakage of hot water through multiple check valves. At Robinson-2 both motor driven pumps were found to be hot, and both motor and steam driven pumps were found to be inoperable at different times. Backleakage at Robinson-2 passed through closed motor-operated isolation valves in addition to multiple check valves. At Farley, both motor and turbine driven pump casings were found hot, although the pumps were not declared inoperable. In addition to multi-train failures, numerous incidents of single train failures have occurred, resulting in the designation of "Steam Binding of Auxiliary Feedwater Pumps" as Generic Issue 93. This generic issue was resolved by Generic Letter 88-03 (Miraglia, 1988), which required licensees to monitor AFW piping temperatures each shift, and to maintain procedures for recognizing steam binding and for restoring system operability.

CC11. Common cause failures have also failed motor operated valves. During the total loss of feedwater event at Davis Besse, the normally-open AFW isolation valves failed to open after they were inadvertently closed. The failure was due to improper setting of the torque switch bypass switch, which prevents motor trip on the high torque required to unseat a closed valve. Previous problems with these valves had been addressed by increasing the torque switch trip setpoint - a fix which failed during the event due to the higher torque required due to high differential pressure across the valve. Similar common mode failures of MOVs have also occurred in other systems, resulting in issuance of Generic Letter 89-10, "Safety Related Motor-Operated Valve Testing and Surveillance (Partlow, 1989)." This generic letter requires licensees to develop and implement a program to provide for the testing, inspection and maintenance of all safety-related MOVs to provide assurance that they will function when subjected to design basis conditions. 
CC12. Oiher component failures have also resulted in AFW multi-train failures. These include out-of-adjustment electrical flow controllers resulting in improper discharge valve operation, and a failure of oil cooler cooling water supply valves to open due to silt accumulation.

\subsubsection{Human Errors}

HEl. The overwhelmingly dominant cause of problems identified during a series of operational readiness evaluations of AFW systems was human performance. The majority of these human performance problems resulted from incomplete and incorrect procedures, particularly with respect to valve lineup information. A study of valve mispositioning events involving human error identified failures in administrative control of tagging and logging, procedural compliance and completion of steps, verification of support systems, and inadequate procedures as important. Another study found that valve mispositioning events occurred most often during maintenance, calibration, or modification activities. Insufficient training in determining valve position, and in administrative requirements for controlling valve positioning were important causes, as was oral task assignment without task completion feedback.

HE2. Turbine driven pump failures have been caused by human errors in calibrating or adjusting governor speed control, poor governor maintenance, incorrect adjustmiant of governor valve and overspeed trin linkages, and errors associated with the trip and throttle valve. TTV-associated errors include physically bumping it, failure to restore it to the correct position after testing, and failures to verify control room indication of TTV position following actuation.

HE3. Mo+or driven pumps have been failed by human errors in mispositioning handswitches, and by procedure deficiencres.

\subsubsection{Design/Engineering Problems and Errors}

DEl. As noted above, the majority of AFW subsystem failures, and the greatest relative system degradation, has been found to result from turbine-driven pump failures. Overspeed trips of Terry turbines controiled by Woodward governors have been a significant source of these failures (AEOD/C602, 1986). In many cases these overspeed trips have been caused by slow response of a Woodward Model EG governor on startup, at plants where full steam flow is allowed immediately. This oversensitivity has been removed by installing a startup steam bypass valve which opens first, allowing a controlled turbine acceleration and buildup of oil pressure to control the governor valve when full steam flow is admitted.

DE2. Overspeed trips of Terry turbines have been caused by condensate in the steam supply lines. Condensate slows down the turbine, causing the governor valve to open farther, and overspeed resilts before the governor valve can respond, after the water slug clears. This was determined to be the cause of the loss-of-all-AFW event at Davis Besse (AEOD/602, 1986), with condensation enhanced due to the long length of the cross-connected steam 1 ines. Repeated tests following a cold-start trip may be successful due to system heat up. 
DE3. Turbine trip and throttle valve (TTV) problems are a significant cause of turbine driven pump failures (IN 84-66). In some cases lack of TTV position indication in the cortrol room prevented recognition of a tripped TTV. In other cases it was possible to reset either the overspeed trip or the TTV without reseting the other. This problem is compounded by the fact that the position of the overspeed trip linkage can be misleading, and the mechanism may lack labels indicating when it is in the tripped position (AEOD/C602, 1986).

DE4. Startup of turbines with Woodward Mode1 PG-PL governors within 30 minutes of shutdown has resulted in overspeed trips when the speed setting knob was not exercised locally to drain oil from the speed setting cylinder. Speed control is based on startup with an empty cylinder. Problems have involved turbine rotation due to both procedure violations and leaking steam. Terry has marketed two types of dump valves for automatically draining the oil after shutdown (AEOD/C602, 1986).

At Calvert Cliffs, a 1987 loss-of-offsite-power event required a quick, cold startup that resulted in turbine trip due to PG-PL governor stability problems. The short-term corrective action was installation of stiffer buffer springs (IN 88-09, 1988). Surveillance had always been preceded by turbine warmup, which illustrates the importance of testing which duplicates service conditions as much as is practical.

DE5. Reduced viscosity of gear box oil heated by prior operation caused failure of a motor driven pump to start due to insufficient lube oil pressure. Lowering the pressure switch setpoint solved the problem, which had not been detected during testing.

DE6. Waterhammer at Palisades resulted in AFW line and hanger damage at both steam generators. The AFW spargers are located at the normal steam generator level, and are frequently covered and uncovered during level fluctuations. Waterhammers in top-feed-ring steam generators resulted in main feedline rupture at Maine Yankee and feedwater pipe cracking at Indian Point-2 (IN 84$32,1984)$.

DE7. Manually reversing the direction of motion of an operating valve has resulted in MOV failures where such loading was not considered in the design (AEOD/C603, 1986). Control circuit design may prevent this, requiring stroke completion before reversal.

DE8. At each of the units of the South Texas Project, space heaters provided by the vendor for use in preinstallation storage of MOVs were found to be wired in parallel to the Class $1 E 125 \mathrm{~V}$ DC motors for several AFW valves (IR $50-489 / 89-11 ; 50-499 / 89-11,1989)$. The valves had been environmentally qualified, but not with the non-safety-relaied heaters energized. 


\subsubsection{Component Failures}

Generic Issue II.E.6.1, "In Situ Testing of Valves" was divided into four sub-issues (Beckjord, 1989), three of which relate directly to prevention of AFW system component failure. At the request of the NRC, in-situ testing of check valves was addressed by the nuclear industry, resulting in the EPRI report, "Application Guidelines for Check Valves in Nuclear Power Plants (Brooks, 1988)." This extensive report provides information on check valve applications, limitations, and inspection techniques. In-situ testing of MOVs was addressed by Generic Letter 89-10, "Safety Related Motor-Operated Valve Testing and Surveillance" (Partlow, 1989) which requires licensees to develop and implement a program for testing, inspection and maintenance of all safetyrelated MOVs. "Thermal Overload Protection for Electric Motors on SafetyRelated Motor-Operated Valves - Generic Issue II.E.6.1 (Rothberg, 1988)" concludes that valve motors should be thermally protected, yet in a way which emphasizes system function over protection of the operator.

CF1. The common-cause steam binding effects of check valve leakage were identified in Section 5.2.1, entry CC10. Numerous single-train events provide additional insights into this problem. In some cases leakage of hot MFW past multiple check valves in series has occurred because adequate valve-seating pressure was limited to the valves closest to the steam generators (AEOD/C404, 1984). At Robinson, the pump shutdown procedure was changed to delay closing the MOVs until after the check valves were seated. At Farley, check valves were changed from swing type to $1 \mathrm{ift}$ type. Check valve rework has been done at a number of plants. Different valve designs and manufacturers are involved in this problem, and recurring leakage has been experienced, even after repair and replacement.

CF2. At Robinson, heating of motor operated valves by check valve leakage has caused thermal binding and failure of AFW discharge valves to open on demand. At Davis Besse, high differential pressure across AFW injection valves resulting from check valve leakage has prevented MOV operation (AEOD/C603, 1986).

CF3. Gross check valve leakage at McGuire and Robinson caused overpressurization of the AFW suction piping. At a foreign PWR it resulted in a severe waterhammer event. At Palo Verde-2 the MFW suction piping was overpressurized by check valve leakage from the AFW system (AEOD/C404, 1984). Gross check valve leakage through idle pumps represents a potential diversion of AFW pump flow.

CF4. Roughly one third of AFW system failures have been due to valve operator failures, with about equal failures for MOVs and AOVs. Almost half of the MOV failures were due to motor or switch failures (Casada, 1989). An extensive study of MOV events (AEOD/C603, 1986) indicates continuing inoperability problems caused by: torque switch/limit switch settings, adjustments, or failures; motor burnout; improper sizing or use of thermal overload devices; premature degradation related to inadequate use of protective devices; damage due to misuse (valve throttling, valve operator hammering); mechanical problems (loosened parts, improper assembly); or the torque switch bypass circuit improperly instailed or adjusted. The study concluded that current 
methods and procedures at many plants are not adequate to assure that MOVs will operate when needed under credible accident conditions. Specifically, a surveillance test which the valve passed might result in undetected valve inoperability due to component failure (motor burnout, operator parts failure, stem disc separation) or improper positioning of protective devices (thermal overload, torque switch, limit switch). Generic Letter 89-10 (Partlow, 198') has subsequently required licensees to implement a program ensuring that MOV switch settings are maintained so that the valves will operate under design basis conditions for the life of the plant.

CF5. Component problems have caused a significant number of turbine driven pump trips (AEOD/C602, 1986). One group of events involved worn tappet nut faces, loose cable connections, loosened set scrows, improperly latched TTVs, and improper assembly. Another involved oil leaks due to component or seal failures, and oil contamination due to poor maintenance activities. Governor oil may not be shared with turbine lubrication oil, resulting in the need for separate oil changes. Electrical component failures included transistor or resistor failures due to moisture intrusion, erroneous grounds and connections, diode failures, and a faulty circuit card.

CF6. Electrohydraulic-operated discharge valves have performed very pcorly, and three of the five units using them have removed them due to recurrent failures. Failures included oil leaks, contaminated oil, and hydraulic pump failures.

CF7. Control circuit failures were the dominant source of motor driven AFW pump failures (Casada, 1989). This includes the controls used for automatic and manual starting of the pumps, as opposed to the instrumentation inputs. Most of the remaining problems were due to circuit breaker failures.

CF8. "Hydraulic lockup" of Limitorque SMB spring packs has prevented proper spring compression to actuate the MOV torque switch, due to grease trapped in the spring pack. During a surveillance at Trojan, failure of the torque switch to trip the TTV motor resulted in tripping of the thermal overload device, leaving the turbine driven pump inoperable for 40 days until the next surveillance (AEOD/E702, 1987). Problems result from grease changes to EXXON NEBULA EP- 0 grease, one of on 1y two greases considered environmentally qualified by Limitorque. Due to lower viscosity, it slowly migrates from the gear case into the spring pack. Grease changeover at Vermont Yankee affected 40 of the older MOVs of which 32 were safety related. Grease relief kits are needed for MOV operators manufactured before 1975. At Limerick, additional grease relief was required for MOV's manufactured since 1975. MOV refurbishment programs may yield other changeovers to EP-O grease.

CF9. For AFW systems using air operated valves, almost half of the system degradation has resulted from failures of the valve controller circuit and its instrument inputs (Casada, 1989). Failures occurred predominantly at a few units using automatic electronic controllers for the flow control valves, with the majority of failures due to electrical hardware. At Turkey Point-3, controller malfunction resulted from water in the Instrument Air system due to maintenance inoperability of the air dryers. 
CF10. For systems using diesel driven pumps, most of the failures were due to start control and governor speed control circuitry. Half of these occurred on demand, as opposed to during testing (Casada, 1989).

CF11. For systems using AOVs, operability requires the availability of, Instrument Air, backup air, or backup nitrogen. However, NRC Maintenance Team Inspections have identified inadequate testing of check valves isolating the safety-related portion of the IA system at several utilities (Letter, Roe to Richardson). Generic Letter 88-14 (Miraglia, 1988), requires 1icensees to verify by test that air-operated safety-related components will perform as expected in accordance with all design-basis events, including a loss of normal IA. 


\subsection{REFERENCES}

Beckjord, E. S. June 30, 1989. Closeout of Generic Issue II.E.6.1, "In Situ Testing of Valves". Letter to V. Stello, Jr., U.S. Nuclear Regulatory Commission, Washington, DC.

Brooks, B. P. 1988. Application Guidel ines for Check Valves in Nuclear Power Plants. NP-5479, Electric Power Research Institute, Palo Alto, CA.

Casada, D. A. 1989. Auxiliary Feedwater System Aging Study. Volume 1. Operating Experience and Current Monitoring Practices. NUREG/CR-5404. U.S. Nuclear Regulatory Commission, Washington, DC.

Gregg, R. E. and R. E. Wright. 1988. Appendix Review for Dominant Generic Contributors. BLB-31-88. Idaho National Engineering Laboratory, Idaho Falls, Idaho.

Miraglia, F. J. February 17, 1988. Resolution of Generic Safety Issue 93, "Steam Binding of Auxiliary Feedwater Pumps" (Generic Letter 88-03). U.S. Nuclear Regulatory Commission, Washington, DC.

Miraglia, F. J. August 8, 1988. Instrument Air Supply System Problems Affecting Safety-Related Equipment (Generic Letter 88-14). U.S. Nuclear Regulatory Commission, Washington, DC.

Partlow, J. G. June 28, 1989. Safety-Related Motor-Operated Valve Testing and Surveillance (Generic Letter 89-10). U.S. Nuclear Regulatory Commission, Washington, DC.

Rothberg, 0. June 1988. Thermal Overload Protection for Electric Motors on Safety-Related Motor-Operated Valves - Generic Issue II.E.6.1. NUREG-1296. U.S. Nuclear Regulatory Commission, Washington, DC.

Travis, R. and J. Taylor. 1989. Development of Guidance for Generic, Functionally Oriented PRA-Based Team Inspections for BWR Plants-Identification of Risk-Important Systems, Components and Human Actions. TLR-A-3874-T6A Brookhaven National Laboratory, Upton, New York.

\section{AEOD Reports}

AEOD/C404. W. D. Lanning. July 1984. Steam Binding of Auxiliary Feedwater Pumps. U.S. Nuclear Regulatory Commission, Washington, DC.

AEOD/C602. C. Hsu. August 1986. Operational Experience Involving Turbine Overspeed Trips. U.S. Nuclear Regulatory Commission, Washington, DC.

AEOD/C603. E. J. Brown. December 1986. A Review of Motor-Operated Valve Performance. U.S. Nuclear Regulatory Commission, Washington, DC. 
AEOD/E702. E. J. Brown. March 19, 1987. MOV Failure Due to Hydraulic Lockup From Excessive Grease in Spring Pack. U.S. Nuclear Regulatory Commission, Washington, $D C$.

AEOD/T416. January 22, 1983. Loss of ESF Auxiliary Feedwater Pump Capability at Trojan on January 22, 1983. U.S. Nuclear Regulatory Commission, Washington, DC.

\section{Information Notices}

IN 82-01. January 22, 1982. Auxiliary Feedwater Pump Lockout Resulting from Westinghouse W-2 Switch Circuit Modification. U.S. Nuclear Regulatory Commission, Washington, DC.

IN 84-32. E. L. Jordan. Apri1 18, 1984. Auxiliary Feedwater Sparger and Pipe Hangar Damage. U.S. Nuclear Regulatory Commission, Washington, DC.

IN 84-66. August 17, 1984. Undetected Unavailability of the Turbine-Driven Auxiliary Feedwater Train. U.S. Nuclear Regulatory Commission, Washington, DC.

IN 87-34. C. E. Rossi. July 24, 1987. Single Failures in Auxiliary Feedwater Systems. U.S. Nuclear Regulatory Commission, Washington, DC.

IN 87-53. C. E. Rossi. October 20, 1987. Auxiliary Feedwater Pump Trips Resulting from Low Suction Pressure. U.S. Nuclear Regulatory Commission, Washington, DC.

IN 88-09. C. E. Rossi. March 18, 1988. Reduced Reliability of Steam-Driven Auxiliary Feedwater Pumps Caused by Instability of Woodward PG-PL Type Governors. U.S. Nuclear Regulatory Commission, Washington, DC.

IN 89-30. R. A. Azua. August 16, 1989. Robinson Unit 2 Inadequate NPSH of Auxiliary Feedwater Pumps. Al so, Event Notification 16375, August 22, 1989. U.S. Nuclear Regulatory Commission, Washington, DC.

\section{Inspection Report}

IR 50-489/89-11; 50-499/89-11. May 26, 1989. South Texas Project Inspection Report. U.S. Nuclear Regulatory Commission, Washington, DC.

NUREG Report

NUREG-1154. 1985. Loss of Main and Auxiliary Feedwater Event at the Davis Besse Plant on June 9, 1985. U.S. Nuclear Regulatory Commission, Washington, DC. 


\section{DISTRIBUTION}

No. of

Copies

\section{OFFSITE}

U.S. Nuclear Regulatory Commission

B. K. Grimes

OWFN 9 A2

F. Conge 1

OWFN 10 E4

A. El Bassioni

OWFN 10 A2

A. R. Johnson

OWFN 14 D1

10 S. M. Long

OWFN 10 A2

K. Campe

OWFN 1 A2

J. Chung

OWFN 10 A2

R. H. Wessman

OWFN 14 DI

2 K. S. West

OWFN 12 H26

U.S. Nuclear Regulatory Commission - Region 1
E. L. Conner
C. W. Hehles
M. W. Hodges
E. M. Kelly
W. J. Lazarus
E. C. McCabe

No. of

Copies

$4 \quad$ Ginna Resident Inspector Office

\section{OFFSITE}

J. H. Taylor

Brookhaven National Laboratory Bldg. 130

Upton, NY 11973

R. Travis

Brookhaven National Laboratory Bldg. 130

Upton, NY 11973

R. Gregg

EG\&G Idaho, Inc.

P.0. Box 1625

Idaho Falls, ID 83415

Dr. D. R. Edwards

Prof. of Nuclear Engineering University of Missouri - Rolla Rolla, MO 65401

\section{ONSITE}

31 Pacific Northwest Laboratory
S. R. Doctor
L. R. Dodd
B. F. Gore (10)
N. E. Maguire-Moffitt
R. Pugh (5)
B. D. Shipp
F. A. Simonen
T. V. Vo (5)
Publishing Coordination
Technical Report File (5) 


\begin{tabular}{|c|c|}
\hline $\begin{array}{l}\text { U.S. NUCLEAR REGULATORY COMMISSION } \\
\text { BIBLIOGRAPHIC DATA SHEET } \\
\text { (see instructions on the reverse) }\end{array}$ & 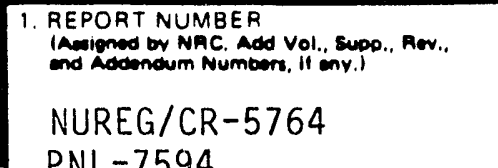 \\
\hline 2. TITLE AND SUBTITLE & \\
\hline Auxiliary Feedwater System Risk-Based Inspection Guide for the & 3. DATE REPORT PUBLISHED \\
\hline & \begin{tabular}{|c|c|} 
MONTH & YEAR \\
September & 1991
\end{tabular} \\
\hline & $\begin{array}{l}\text { 4. FIN OR GRANT.NUMBER } \\
\text { L1310 } \\
\end{array}$ \\
\hline 5. AUTHOR(S) & 6. TYPE OF REPORT \\
\hline R. Pugh, B. F. Gore, T. V. Vo, N. E. Moffitt & Technical \\
\hline & $\begin{array}{l}\text { 7. PERIOD COVERED IInCluAve Doles/ } \\
8 / 90 \text { to } 8 / 91\end{array}$ \\
\hline 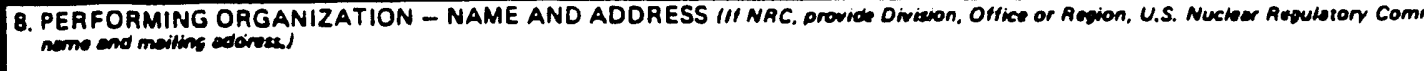 & neniscion, and mailing cooress; it contrector, provide \\
\hline Pacific Northwest Laboratory & \\
\hline Richland, WA 99352 & \\
\hline 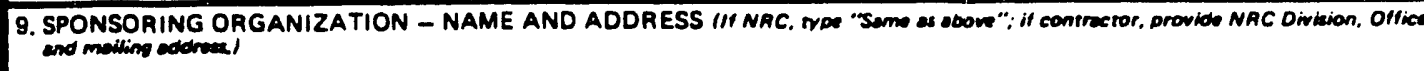 & co or Ragion. U.S. Nucteor Regulstory Commission. \\
\hline $\begin{array}{l}\text { Division of Radiation Protection and Emergency Preparedness } \\
\text { Office of Nuclear Reactor Regulation } \\
\text { U.S. Nuclear Regulatory Cornmission } \\
\text { Washington, DC } 20555\end{array}$ & 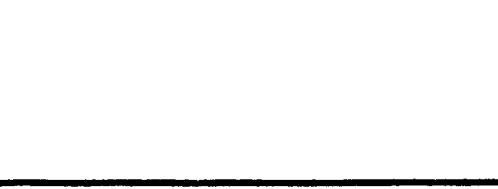 \\
\hline 10. SUPPLEMENTARY NOTES & \\
\hline $\begin{array}{l}\text { In a study sponsored by the U.S. Nuclear Regulatory Comn } \\
\text { Pacific Northwest Laboratory has developed and applied a meth } \\
\text { deriving plant-specific risk-based inspection guidance for th } \\
\text { feedwater (AFW) system at pressurized water reactors that hav } \\
\text { probabilistic risk assessment (PRA). This methodology uses } \\
\text { results and plant operating experience information. Existing } \\
\text { inspection guidance information recently developed for the NF } \\
\text { plants was used to identify generic component failure modes. } \\
\text { was then combined with plant-specific and industry-wide compc } \\
\text { and failure data to identify failure modes and failure mechar } \\
\text { system at the selected plants. Ginna was selected as the eig } \\
\text { study. The product of this effort is a prioritized listing } \\
\text { which have occurred at the plant and at other PWRs. This } 1 \text { is } \\
\text { for use by NRC inspectors in the preparation of inspection pl } \\
\text { AFW risk-important components at the Ginna plant. }\end{array}$ & $\begin{array}{l}\text { mission (NRC), } \\
\text { hodology for } \\
\text { he auxiliary } \\
\text { ve not undergone } \\
\text { existing PRA } \\
\text { g PRA-based } \\
\text { RC for various } \\
\text { This information } \\
\text { onent information } \\
\text { nisms for the AFW } \\
\text { ghth plant for } \\
\text { of AFW failures } \\
\text { sting is intended } \\
\text { lans addressing } \\
\end{array}$ \\
\hline 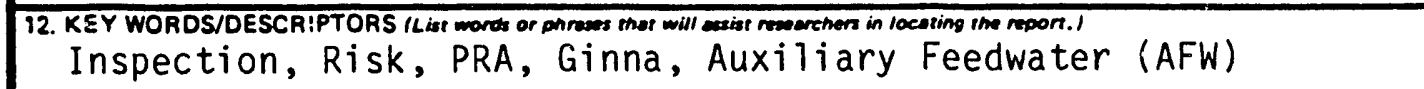 & $\begin{array}{l}\text { 13. AVAILABILITY STATEMENT } \\
\text { Unlimited }\end{array}$ \\
\hline & 14. SECUAITY CLASSIFICATION \\
\hline & $\begin{array}{l}\text { IThis poopl } \\
\text { Unclassified }\end{array}$ \\
\hline & TThis Acoont \\
\hline & Unclassified \\
\hline & \\
\hline & 16. PRICE \\
\hline
\end{tabular}



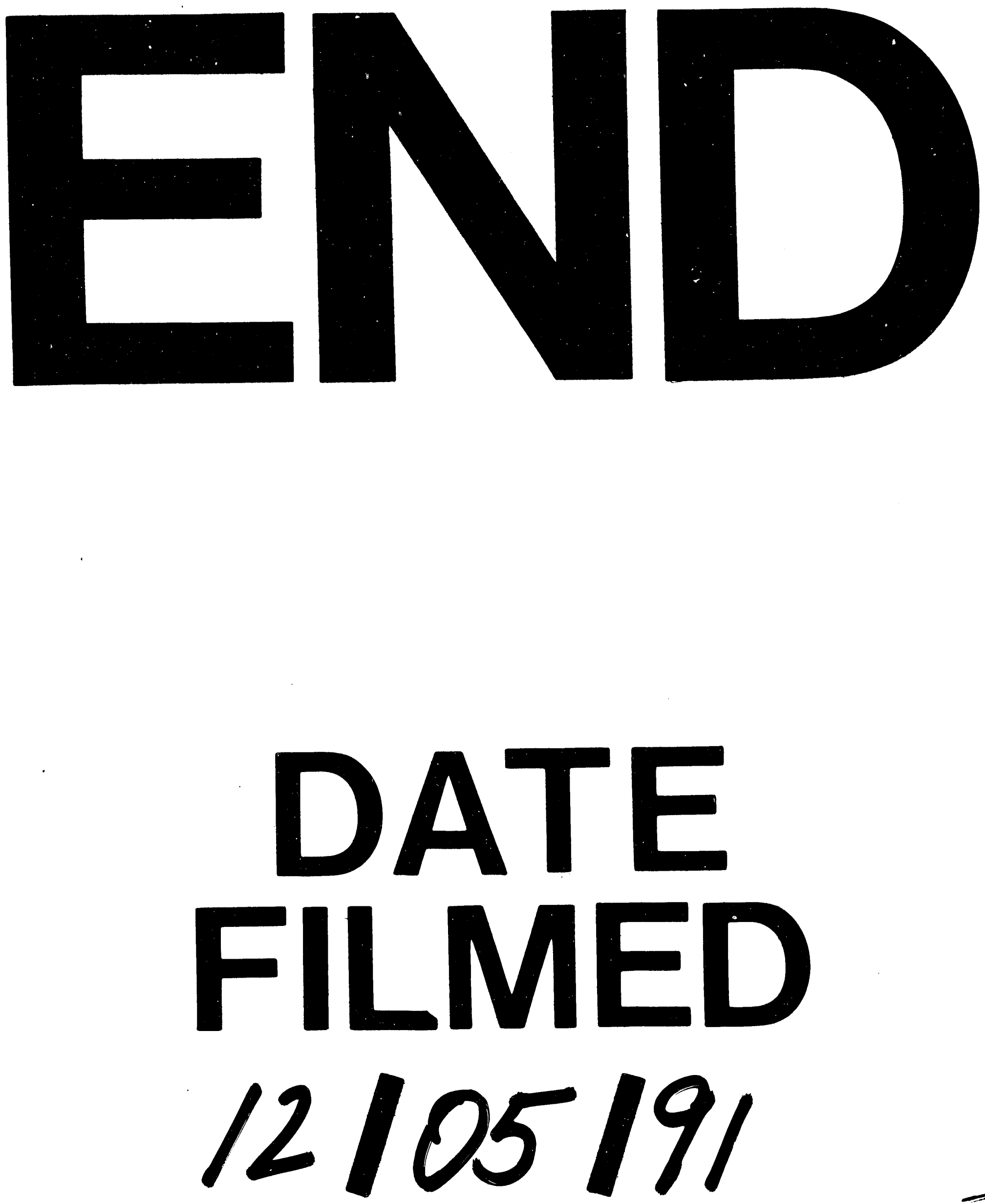

I

$I$ 
